\title{
IMPLEMENTASI PERLINDUNGAN HUKUM OBJEK JAMINAN \\ DALAM SISTEM PENDAFTARAN FIDUSIA ELEKTRONIK \\ (Studi Pada Kantor Wilayah Hukum dan HAM Provinsi Lampung)
}

\author{
Nadya Fallanda Sutedjo1, Muhammad Iqbal², Garda Arian Gunawan ${ }^{3}$ \\ Fakultas Hukum Universitas Bandar Lampung \\ Jl. ZA Pagar Alam No 26 Labuhan Ratu Bandar Lampung
}

Email: nadya.sutedjo@yahoo.com; Muhammad.iqbal@ubl.ac.id; garda.arian@ubl.ac.id

\begin{abstract}
ABSTRAK
The Fiduciary Guaranty Act (AJF) must be made in an authentic form and an AJF registration online. The Fiduciary Registration Office manually registers fiduciary guarantees and it turns out that the implementation has several obstacles, including the failure to achieve one day service because the requests that go far exceed the capabilities of existing human resources and facilities and to minimize corruption and collusion. then the government feels the need to create an electronic system (online system) registration service pattern. The research problem that will be discussed in this paper is the implementation of an electronic fiduciary registration system at the fiduciary registration office of the Ministry of Law and Human Rights of Lampung Province and the legal protection of object guarantees in electronic fiduciary registration. Juridical normative and empirical research methods, using secondary and primary data, obtained from library studies and field studies. Based on the results of research and discussion, it is known that in the electronic fiduciary registration system there are differences in the way of registration, the issuance of certificates, and the executive power inherent in the object of fiduciary guarantee. With the registration of a fiduciary certificate, the creditor has the right of preference and the fiduciary guarantee certificate has executorial power as well as a court decision that has obtained permanent legal force. Electronic fiduciary certificate registration has a time limit of 30 days from the issuance of a fiduciary deed, if it is not immediately registered within 30 days, the fiduciary deed will expire and need more time to make it. To realize legal certainty and fulfill the principle of publicity in the registration of fiduciary guarantees, the parties should immediately register objects that have been burdened with fiduciary guarantees.
\end{abstract}

Keywords: Implementation, Object Assurance, Fiduciary Electronics.

\section{PENDAHULUAN}

Memasuki era globalisasi yang mengharuskan setiap negara melakukan pembangunan dalam segala aspek kehidupan merupakan upaya untuk mewujudkan tujuan nasional yang tertuang dalam Pembukaan Undang-Undang Dasar Negara Republik Indonesia Tahun 1945 Alenia 4, yakni melindungi segenap bangsa dan seluruh tumpah darah Indonesia, memajukan kesejahteraan umum, mencerdaskan kehidupan bangsa dan ikut melaksanakan ketertiban dunia berdasarkan kemerdekaan, perdamaian abadi dan keadilan sosial. Sebagaimana kita ketahui pembangunan ekonomi, sebagai bagian dari pembangunan nasional, diharapkan dapat menciptakan dan menjadikan masyarakat Indonesia menuju ke masyarakat yang adil dan makmur berdasarkan Pancasila dan UndangUndang Dasar Negara Republik Indonesia Tahun 1945.

Dalam rangka memelihara dan meneruskan pembangunan yang berkesinambungan, para pelaku pembangunan baik pemerintah maupun masyarakat, baik perorangan maupun badan hukum, memerlukan dana yang besar. Seiring dengan meningkatnya kegiatan pembangunan, meningkat pula kebutuhan tehadap pendanaan, yang sebagian besar dana yang diperlukan untuk memenuhi kebutuhan tersebut diperoleh 
melalui kegiatan pinjam meminjam. Konstruksi hukum yang ada saat ini mengatur mengenai pengumpulan dana masyarakat, baik dalam bentuk dana jangka pendek maupun dana jangka panjang untuk kemudian "didistribusikan" kembali kepada anggota masyarakat yang memerlukan dalam bentuk pernyataan jangka pendek maupun jangka panjang (melalui pranata pasar modal), serta dalam bentuk pemberian pinjaman jangka pendek maupun jangka panjang (melalui pasar uang, dan khususnya institusi perbankan).

Menurut Mariam Darus Badrulzaman, (1994:16) Institusi perbankan memiliki peranan yang strategis di dalam trilogi pembangunan, karena perbankan adalah suatu wahana yang dapat menghimpun dan menyalurkan dana masyarakat secara efektif dan efisien, yang berdasarkan dengan demokrasi ekonomi mendukung pelaksanaan pembangunan nasional dalam rangka meningkatkan pemerataan pembangunan dan hasil-hasilnya, pertumbuhan ekonomi dan stabilitas nasional ke arah peningkatan taraf hidup rakyat banyak.

Fungsi dari perbankan menurut Thomas Suyatno, (2007: 12) adalah menghimpun dan menyalurkan dana dari dan kepada masyarakat yang membutuhkan dana guna menunjang pembangunan. Dalam hal ini perbankan memberi jalan dengan pemberian kredit kepada masyarakat. Istilah kredit berasal dari bahasa Yunani "Credere" yang berarti kepercayaan (truth atau faith). Oleh karena itu, dasar dari kredit adalah kepercayaan. Seseorang atau badan yang memberikan kredit (kreditur) percaya bahwa penerima kredit (debitur) di masa mendatang akan sanggup untuk memenuhi segala sesuatu yang telah dijanjikan.
Menurut Undang-Undang Nomor 10 Tahun 1998 tentang Perbankan, yang dimaksud dengan kredit adalah : "Penyediaan uang atau tagihan-tagihan yang dapat disamakan dengan itu berdasarkan persetujuan pinjam meminjam antara bank dengan pihak lain dalam hal mana pihak peminjam berkewajiban melunasi utangnya setelah jangka waktu tertentu dengan jumlah bunga yang telah ditetapkan". Kredit yang diberikan kepada debitur didasarkan atas kepercayaan, yang berarti bahwa kreditur akan memberikan kredit apabila ia percaya bahwa debitur benar-benar mampu akan mengembalikan pinjaman pada waktu yang ditentukan.

Adanya kredit mempunyai tujuan yang penting, tujuan kredit menurut Thomas Suyatno adalah :

1. Turut mengsukseskan program pemerintah dalam bidangekonomi dan pembangunan.

2. Peningkatan aktivitas perushaan agar dapat menjalankan fungsinya guna menjamin terpenuhinya kebutuhan masyarakat.

3. Memperoleh laba agar kelangsungan hidup perusahaan terjamin, dan dapat memperluas usahanya.

Karena pemberian kredit atas dasar kepercayaan dari kreditur kepada debitur, maka pemberian kredit tersebut berdasar atas prinsip kehati-hatian. Berdasarkan prinsip kehati-hatian tersebut, sarana pengaman dalam pengambilan kredit adalah dengan adanya jaminan baik berupa jaminan kebendaan maupun jaminan perorangan. Salah satu macam dari jaminan kebendaan adalah jaminan fidusia. Berbicara mengenai jaminan fidusia, fidusia berasal dari kata "fides" yang berarti kepercayaan (Supianto, 2015:13). Pengertian Fidusia menurut Pasal 1 sub 1 
Undang-Undang Nomor 42 Tahun 1999 tentang Jaminan Fidusia "Fidusia adalah pengalihan hak kepemilikan suatu benda atas dasar kepercayaan dengan ketentuan bahwa benda yang hak kepemilikannya dialihkan tersebut tetap dalam penguasaan pemilik benda". Pengertian jaminan fidusia menurut Pasal 1 angka 2 Undang-Undang Nomor 42 Tahun 1999 tentang Jaminan Fidusia adalah :

"Hak jaminan atas benda bergerak baik yang berwujud maupun yang tidak berwujud dan benda tidak bergerak khususnya bangunan yang tidak dapat dibebani hak tanggungan sebagaimana yang dimaksud dalam Undang-Undang Nomor 4 Tahun 1996 tentang Hak Tanggungan yang tetap berada dalam penguasaan pemberi fidusia, sebagai aggunan bagi pelunasan utang tertentu, yang memberikan kedudukan yang diutamakan kepada penerima fidusia terhadap kreditur lainnya."

Menurut Aermadepa, (2012) Jaminan fidusia adalah hak jaminan atas benda bergerak baik berwujud maupun yang tidak berwujud dan benda tidak bergerak khususnya bangunan yang tidak dapat dibebani hak tanggungan sebagaimana dimaksud dalam Undang-Undang No. 4 Tahun 1996 tentang Hak Tanggungan atas tanah beserta benda-benda yang berkaitan dengan tanah yang tetap dalam penguasaan pemberi fidusia, sebagai guna bagi pelunasan uang tertentu, yang memberikan kedudukan yang diutamakan kepada penerima fidusia terhadap kreditur lainnya.

Berdasarkan ketentuan UndangUndang Nomor 42 Tahun 1999 tentang Jaminan Fidusia. Fidusia harus dilakukan dalam dua tahap yaitu pembebanan fidusia dan pendaftaran fidusia. Pembebanan fidusia harus dilakukan dengan akta notariil dan selanjutnya akta notariil tersebut harus didaftarkan pada kantor pendaftaran fidusia. Selanjutnya Kantor Pendaftaran Fidusia akan melakukan pencatatan jaminan fidusia dalam buku daftar fidusia, dimana pencatatan ini dianggap sebagai akhirnya jaminan fidusia. Ini berarti tidak ada jaminan fidusia tanpa dilakukan pendaftaran pada Kantor Pendaftaran Fidusia.

Proses pendaftaran sertifikat Fidusia yang membutuhkan waktu lama kini tidak akan terjadi lagi. Dikarenakan sejak tanggal 5 Maret 2013, Direktorat Jenderal Administrasi Hukum Umum Kementerian Hukum dan Hak Asasi Manusia (Kemenkumham) telah meluncurkan sistem fidusia elektronik. Kepala Humas Ditjen Administrasi Hukum Umum Sucipto memaparkan sistem pendaftaran fidusia secara elektronik ini diluncurkan oleh Kementrian Hukum dan HAM dalam rangka meningkatkan pelayanan Kementerian sesuai dengan amanat Undang-Undang Pelayanan Publik.

Hadirnya sistem elektronik setiap permohonan pendaftaran akan selesai dalam waktu 7 menit dan notaris bisa langsung mem-print out sertifikat itu sendiri. Kepala Humas Ditjen Administrasi Hukum Umum Sucipto mengatakan sistem pendaftaran secara elektronik dapat meminimalisir hal-hal yang tidak dinginkan, "Sistem elektronik bisa meminimalisir Korupsi, Kolusi dan Nepotisme (KKN), karena dalam melakukan pendaftaran sertifikat hanya dapat di akses notaris bersangkutan dengan pin dan user ID-nya. Jadi interaksi dengan petugas hampir tidak ada".

Dikeluarkannya Peraturan Kementrian Hukum dan HAM Nomor 9 Tahun 2013 tentang Fidusia Elektronik, notaris makin 
mendapat kemudahan dan perlakuan terhormat dari pemerintah dalam masalah pelayanan publik.

Persoalan lain yang muncul dalam forum itu dilontarkan Efril dari Bintang Finance. Dia menuturkan pengalaman pendaftaran fidusia baru selesai sekitar 40 hingga 45 hari. Hal tersebut akan menjadi masalah apabila multifinance akan menarik kendaraan, namun sertifikatnya belum ada. Muhamad Fajar, Kepala Seksi Penerimaan dan Pemrosesan Pendaftaran Fidusia Ditjen Administrasi Hukum Umum Kementerian Hukum dan Hak Asasi Manusia (Kemenkumham), tidak menampik apabila ada pendaftaran fidusia yang diproses cukup lama. Dia memberikan usulan kepada multifinance agar dapat mempecepat proses pendaftaran.

Akan tetapi pada kenyataannya dalam praktik, masih saja banyak dijumpai dalam fidusia elektronik masalah masalah antara lain tidak tercantumnya objek yang dijaminkan pada sertifikat jaminan fidusia , uraian benda benda yang menjadi obyek jaminan fidusia dalam tampilan hanya tertulis sesuai yang tertuang atau termaktub dalam akta notaris yang diperoleh sebagaimana tersebut di atas, maka seorang notaris dihadapannya dapat dibuat sampai ribuan akta fidusia yang akan didaftarkan, Bahwa akta yang dibuat dihadapan notaris apakah sudah memenuhi syarat syarat yang ditentukan sesuai dengan ketentuan Undang-Undang Jabatan Notaris Nomor 30 tahun 2004 sebagaimana diubah dengan Undang-Undang Nomor 2 tahun 2014 tentang Jabatan Notaris.

Berdasarkan uraian uraian diatas maka penulis tertarik untuk mengkaji lebih lanjut mengenai implementasi perlindungan hukum objek jaminan dalam sistem pendaftaran fidusia elektronik serta faktor- faktor yang mendukung maupun menghambat proses fidusia elektronik. Permasalahn dalam penelitian ini adalah:

a. Bagaimana pelaksanaan sistem pendaftaran fidusia elektronik pada kantor pendaftaran fidusia Kementrian Hukum dan HAM Provinsi Lampung?

b. Bagaimana perlindungan hukum objek jaminan dalam pendaftaran fidusia elektronik?

Metode penelitian yang digunakan dalam penelitian ini dilakukan secara yuridis normatif dan empiris, pengumpulan data menggunakan data sekunder dan primer yang diperoleh dari studi kepustakaan dan studi lapangan, setelah data terkumpul kemudian dianalisis secara kualitatif untuk mendapatkan kesimpulan.

\section{PEMBAHASAN}

\section{A. Sistem pendaftaran fidusia elektronik pada kantor pendaftaran fidusia Kementrian Hukum dan HAM Provinsi Lampung.}

Pendaftaran jaminan Fidusia mulai menggeliat ketika pada oktober 2012 Menteri Keuangan mengeluarkan Peraturan Menteri Keuangan nomor 130/PMK.010/2012 tentang Pendaftaran Jaminan Fidusia Bagi Perusahaan Pembiayaan Yang Melakukan Pembiayaan Konsumen Untuk Kendaraan Bermotor Dengan Pembebanan Jaminan Fidusia. Peraturan ini intinya mewajibkan semua lembaga pembiayaan non bank dalam pembiayaan kendaraan bermotor untuk mendaftarkan jaminan Fidusia paling lama 30 hari sejak perjanjian dengan konsekuensi larangan untuk melakukan eksekusi dalam hal kegagalan bayar (default) dan pencabutan izin operasi lembaga keuangan tersebut. 
Kebijakan ini telah berbuntut kepada lonjakan jumlah pendaftaran fidusia sampai tiga kali lipat pada kantor-kantor pendaftaran fidusia. Terjadi tunggakan pendaftaran Fidusia luar biasa pada kantorkantor pendaftaran fidusia sepanjang kuartal akhir tahun 2012. Karena perusahaan pembiayaan yang selama ini mengabaikan kewajiban pendaftaran dipaksa untuk melakukan pendaftaran. Situasi ini berlangsung sampai Februari 2013, ketika Kementerian Hukum dan HAM akhirnya meluncurkan pendaftaran fidusia secara elektronik sebagai pengganti sistem manual.

Melalui Peraturan Menteri Hukum dan HAM Nomor 8 tahun 2013 tentang Pendelegasian Penandatanganan Sertifikat Jaminan Fidusia Secara Elektronik, Peraturan Menteri Hukum dan HAM nomor 9 tahun 2013 tentang Pemberlakuan Pendaftaran Jaminan Fidusia Secara Elektronik, Peraturan Menteri Hukum dan HAM nomor 10 tahun 2013 tentang Tata Cara Pendaftaran Jaminan Fidusia Secara Elektronik dan Surat Edaran Dirjen Administrasi Hukum Umum Nomor AHU06.OT.03.01 Tahun 2013 tentang Operasionalisasi Sistem Pendaftaran Fidusia Elektronik (online) pendaftaran Fidusia telah sepenuhnya dilakukan secara online, dan menutup lembaran pendaftaran Fidusia manual ke dalam khazanah sejarah. Pasca fidusia online, waktu yang diperlukan untuk melakukan pendaftaran Fidusia dipotong menjadi hanya 7 menit.

Selanjutnya, Kementrian Hukum dan HAM terus melakukan penyempurnaan. Kuartal pertama 2015 pemerintah telah mengesahkan Peraturan Pemerintah Nomor 21 Tahun 2015 tentang Tata Cara Pendaftaran Jaminan Fidusia Dan Biaya Pembuatan Akta Jaminan Fidusia yang merubah Peraturan Pemerintah Nomor 86
Tahun 2000 Tata Cara Pendaftaran Jaminan Fidusia Dan Biaya Pembuatan Akta Jaminan Fidusia. Pemerintah juga telah mengatur kembali tarif penerimaan negara bukan pajak fidusia melalui Peraturan Pemerintah Republik Indonesia Nomor 10 Tahun 2015 yang antara lain menghapuskan Pendapatan Negara Bukan Pajak (PNBP) bagi pencabutan pendaftaran, yang diharapkan mendorong kepatuhan pemberi fidusia untuk melakukan pencabutan.

Selain itu, fasilitas fidusia elektronik sendiri telah menjalani setidaknya satu kali penyempurnaan. Pada september 2014 dalam kerangka AHU online, sistem fidusia online baru yang memuat informasi lebih komprehensif diluncurkan oleh Ditjen Administrasi Hukum Umum Kementrian hukum dan HAM.

Berdasarkan Pasal 37 ayat (2) dan Pasal 39 Undang-Undang Nomor 42 Tahun 1999 tentang Jaminan Fidusia dibentuk Kantor Pendaftaran Fidusia yang berada dalam lingkup tugas Kementerian Hukum dan Hak Asasi Manusia dengan wilayah kerja mencakup seluruh wilayah Indonesia. Dalam memberikan pelayanan kepada masyarakat, berdasarkan Peraturan Pemerintah Nomor 86 Tahun 2000 tentang Tata Cara Pendaftaran Jaminan Fidusia dan Biaya Pembuatan Akta Jaminan Fidusia, Kantor Pendaftaran Fidusia melakukan pendaftaran jaminan fidusia secara manual dan ternyata pada penerapannya memiliki beberapa kendala, antara lain tidak tercapainya pelayanan one day service karena permohonan yang masuk sangat banyak melampaui kemampuan sumber daya manusia dan sarana yang ada. Untuk mengatasi permasalahan tersebut, maka pemerintah merasakan perlu diciptakan pola pelayanan pendaftaran jaminan fidusia secara elektronik (online system). 
Dalam hal ini maka terbitlah Peraturan Pemerintah Republik Indonesia Nomor 21 tahun 2015 tentang Tata Cara Pendaftaran Jaminan Fidusia dan Biaya Pembuatan Akta Jaminan Fidusia.

Menurut Pasal 1 Peraturan Pemerintah Republik Indonesia Nomor 21 tahun 2015 tentang Tata Cara Pendaftaran Jaminan Fidusia dan Biaya Pembuatan Akta Jaminan Fidusia, Permohonan pendaftaran jaminan fidusia, permohonan perbaikan sertifikat jaminan fidusia, permohonan perubahan sertifikat jaminan fidusia, dan pemberitahuan penghapusan sertifikat jaminan fidusia diajukan oleh penerima fidusia, kuasa atau wakilnya kepada Menteri melalui sistem pendaftaran jaminan fidusia secara elektronik.

\section{Perbedaan Antara Pendaftaran Fidusia Elektronik dan Fidusia Manual
a. Indikator Pembeda: Peraturan per undang- undangan

Fidusia Manual: Peraturan Pemerintah Republik Indonesia Nomor 26 tahun 2000 tentang Tata Cara Pendaftaran Jaminan Fidusia dan Biaya Pembuatan Akta Jaminan Fidusia

Fidusia Elektronik : Peratutan Pemerintah Republik Indonesia Nomor 21 tahun 2015 tentang Tata Cara Pendaftaran Jaminan Fidusia dan Biaya Pembuatan Akta Jaminan Fidusia

Analisis : Peraturan Pemerintah Republik Indonesia Nomor 26 tahun 2000 tentang Tata Cara Pendaftaran Jaminan Fidusia dan Biaya Pembuatan Akta Jaminan Fidusia sudah tidak sesuai dengan perkembangan hukum dan kebutuhan masyarakat sehingga diganti dengan Peratutan Pemerintah Republik Indonesia Nomor 21 tahun 2015 tentang Tata Cara Pendaftaran Jaminan Fidusia dan Biaya Pembuatan Akta Jaminan Fidusia yang didalamnya berisi tentang pendaftaran fidusia secara elektronik

b. Indikator Pembeda: Cara Pendaftaran

Fidusia Manual : Datang langsung ke kementrian hukum dan HAM untuk mendaftarkan sertifikat fidusia

Fidusia Elektronik: Melalui website https://www.ahu.go.id/

Analisis : Pendafataran melalu website mempermudah pemohon untuk mendaftarkan sertifikat fidusia karena tidak perlu mendatangi kementrian hukum dan HAM secara langsung dan bisa dilakukan dimana saja, cara ini juga untuk menghindari korupsi kolusi nepotisme yang hadir dalam pendaftaran fidusia secara manual atau dengan mendatangi langsung kementrian hukum dan HAM

c. Indikator Pembeda: Waktu terbit sertifikat

Fidusia Manual : Pendaftaran fidusia secara manual membutuhkan waktu setidaknya 30 hari setelah didaftarkan

Fidusia Elektronik : Pendaftaran fidusia secara elektronik hanya membuytuhkan waktu 7 menit

Analisis : Waktu terbit sertifikat pada pendaftaran fidusia elektronik jauh lebih cepat dan lebih efisien dari fidusia secara manual dengan itu fidusia secara elektronik sangat 
membantu pemohon yang ingin mendaftarkan sertifikat fidusia

d. Indikator Pembeda : Kekuatan eksekutorial

Fidusia Manual :Sertifikat jaminan fidusia yang mempunyai kekuatan eksekutorial yang sama dengan putusan pengadilan yang mempunyai kekuatan hukum tetap

Fidusia Elektronik : Sertifikat jaminan fidusia secara elektronik tidak berbeda kekuatannya dengan fidusia manual karena sama sama mempunyai kekuatan eksekutorial yang sama dengan keputusan pengadilan

Analisis : Jika debitur wanprestasi, kreditur sebagai penerima fidusia dapat melakukan penjualan benda jaminan secara langsung dengan bantuan kantor lelang dan tidak perlu meminta fiat pengadilan. Namun, eksekusi terhadap objek jaminan dapat dilaksanakan apabila jaminan fidusia tersebut telah didaftarkan.

Cara pendaftaran fidusia elektronik yang pertama adalah dengan membuka website Direktorat Jenderal Administrasi Hukum Umum lalu memilih fidusia. Terdapat 4 pilihan yaitu Notaris, Korporasi, Ritel dan kanwil. Opsi notaris adalah pilihan masuk bagi notaris yang ingin mendaftarkan fidusia secara elektronik. Opsi Korporasi adalah pilihan masuk untuk perusahaan pembiayaan dan lembaga perbankan. Opsi ritel adalah pilihan masuk untuk perorangan atau badan usaha baik berbadan hukum maupun bukan berbadan hukum. Opsi yang terakhir adalah kanwil yang merupakan pilihan masuk untuk Kantor Wilayah Hukum dan HAM.

Setelah memilih salah satu dari opsi diatas maka akan terdapat 2 pilihan yaitu register atau $\log$ in. Seorang notaris tentunya memilih $\log$ in karena sudah terdaftar di Direktorat Jenderal Administrasi Hukum Umum. Apabila belum memiliki akun maka kita diharuskan untuk register atau mendaftar.

Dalam form pendaftaran terdapat 3 pilihan pada menu pilih jenis yaitu perseorangan, badan usaha berbadan hukum, dan yang terakhir badan usaha bukan berbadan hukum. Daftar nama di isi sesuai dengan nama didalam kartu tanda penduduk. Daftar nomor NPWP diisi sesuai dengan NPWP yang berlaku. Daftar NIK diisi sesuai dengan nomor induk KTP yang berlaku. Daftar alamat diisi sesuai dengan alamat yang tertera di KTP yang berlaku. Daftar nomor telepon diisi sesuai dengan nomor telepon yang aktif. Lalu yang terakhir Daftar email diisi dengan email yang aktif digunakan.

Syarat dari pembuatan akun fidusia adalah menyertakan scan gambar dari NPWP, foto pemohon dan scan asli kartu tanda penduduk (KTP). Lalu klik daftar. Pada gambar di atas pemohon harus mencentang atau menyetujui bahwa data yang diisi pada format isian pemohon akses pendaftaran jaminan fidusia sudan benar dan dokumen untuk permohonan akses pendaftaran jaminan fidusia telah lengkap sebelum mengisi format isian. Jika dalam proses pengisian data pada format tidak sesuai dengan data yang sebenarnya maka pemohon harus bersedia menerima sanksi pidana, perdata dan sanksi administratif sesuai dengan peraturan perundang-undangan.

Setelah berhasil membuat akun, maka lanjutlah $\log$ in lalu memilih menu 
pendaftaran fidusia. Tampilan yang muncul pada website terdapat pada lampiran.

Dalam form isian pendaftaran jaminan fidusia dibagi menjadi 7 bagian yaitu:

a) Indentitas pemberi fidusia: Berisi biodata pemberi fidusia (pemilik barang atau yang akan mendapatkan kredit).

b) Indentitas penerima fidusia: Biodata penerima fidusia (pemberi kredit).

c) Akta notaris jaminan fidusia:

d) Perjanjian pokok:

e) Uraian obyek jaminan fidusia:

f) Nilai jaminan:

g) Nilai obyek jaminan fidusia:

Permohonan pendaftaran jaminan fidusia diajukan dalam jangka waktu paling lama 30 (tiga puluh) hari terhitung sejak tanggal pembuatan akta jaminan fidusia (Pasal 4). Permohonan pendaftaran jaminan fidusia yang telah memenuhi ketentuan tersebut dibuktikan dengan diperolehnya bukti pendaftaran. Pemohon melakukan pembayaran biaya pendaftaran jaminan fidusia melalui bank persepsi berdasarkan bukti pendaftaran. Pendaftaran jaminan fidusia dicatat secara elektronik setelah pemohon melakukan pembayaran biaya pendaftaran jaminan fidusia. Jaminan fidusia lahir pada tanggal yang sama dengan tanggal jaminan fidusia dicatat. Sertifikat jaminan fidusia ditandatangani secara elektronik oleh pejabat pada Kantor Pendaftaran Fidusia. Sertifikat jaminan fidusia dapat dicetak pada tanggal yang sama dengan tanggal jaminan fidusia dicatat.

Apabila terjadi kesalahan pengisian data dalam permohonan pendaftaran jaminan fidusia yang diketahui setelah sertifikat jaminan fidusia dicetak, penerima fidusia, kuasa atau wakilnya harus mengajukan permohonan perbaikan sertifikat jaminan fidusia kepada Menteri. Permohonan perbaikan sertifikat jaminan fidusia diajukan dalam jangka waktu paling lama 30 (tiga puluh) hari terhitung sejak tanggal sertifikat jaminan fidusia diterbitkan.

Dalam Pasal 11 (ayat) 2 Peraturan Pemerintah Republik Indonesia Nomor 21 tahun 2015 tentang Tata Cara Pendaftaran Jaminan Fidusia dan Biaya Pembuatan Akta Jaminan Fidusia permohonan perubahan sertifikat jaminan fidusia sebagaimana dimaksud pada ayat (1) paling sedikit memuat:

a. nomor dan tanggal sertifikat terakhir;

b. nama dan tempat kedudukan notaris;

c. data perubahan; dan

d. keterangan perubahan.

Permohonan perubahan sertifikat jaminan fidusia melalui bank persepsi berdasarkan bukti pendaftaran. Pendaftaran perubahan sertifikat jaminan fidusia dicatat setelah pemohon melakukan pembayaran. Sertifikat perubahan atas sertifikat jaminan fidusia sebagaimana dimaksud dalam Pasal 7 Peraturan Pemerintah Republik Indonesia Nomor 21 tahun 2015 tentang Tata Cara Pendaftaran Jaminan Fidusia dan Biaya Pembuatan Akta Jaminan Fidusia dapat dicetak setelah pembayaran biaya permohonan dilakukan. Sertifikat perubahan dapat dicetak pada tanggal yang sama dengan tanggal permohonan perubahan sertifikat jaminan fidusia dicatat. sertifikat perubahan ditandatangani secara elektronik oleh pejabat pada Kantor Pendaftaran Fidusia.

Apabila jaminan fidusia hapus karena hapusnya utang yang dijamin dengan fidusia, pelepasan hak atas jaminan fidusia oleh penerima fidusia, atau musnahnya benda yang menjadi objek jaminan fidusia, maka penerima fidusia, kuasa atau 
wakilnya, wajib memberitahukan kepada Menteri dalam jangka waktu paling lama 14 (empat belas) hari terhitung sejak tanggal hapusnya jaminan fidusia.

Berdasarkan pemberitahuan penghapusan tersebut, jaminan fidusia dihapus dari daftar jaminan fidusia dan diterbitkan keterangan penghapusan yang menyatakan sertifikat jaminan fidusia yang bersangkutan tidak berlaku lagi. Jika penerima fidusia, kuasa atau wakilnya tidak memberitahukan penghapusan jaminan fidusia maka jaminan fidusia yang bersangkutan tidak dapat didaftarkan kembali.

Pembuatan akta jaminan fidusia dikenakan biaya yang besarnya ditentukan berdasarkan nilai penjaminan, dengan ketentuan sebagai berikut:

a. nilai penjaminan sampai dengan Rp100.000.000,00 (seratus juta rupiah), biaya pembuatan akta paling banyak 2,5\% (dua koma lima perseratus);

c. nilai penjaminan di atas Rp100.000.000,00 (seratus juta rupiah) sampai dengan Rp1.000.000.000,00,(satu miliar rupiah), biaya pembuatan akta paling banyak 1,5\% (satu koma lima perseratus); dan

d. nilai penjaminan di atas Rp1.000.000.000,00 (satu miliar rupiah), biaya pembuatan akta berdasarkan kesepakatan antara notaris dengan para pihak, tetapi tidak melebihi 1\% (satu perseratus) dari objek yang dibuatkan aktanya.

Pelayanan jaminan fidusia menggunakan sistem dalam jaringan (online) bisa diakses melalui https://www.ahu.go.id/.

Dengan penerapan sistem ini, maka para pendaftar tidak perlu lagi melakukan tatap muka dengan petugas di loket dan di sisi lain penerapan sistem ini juga untuk meningkatkan kemudahan berusaha di Indonesia.

\section{B. Perlindungan Hukum Objek Jaminan Dalam Pendaftaran Fidusia Elektronik}

Undang-Undang jaminan fidusia mensyaratkan bahwa benda yang dibebani jaminan fidusia wajib didaftarkan, terhadap benda jaminan fidusia yang tidak didaftarkan maka tidak mempunyai manfaat pendaftaran antara lain:

1. Mempunyai hak mendahului (preference)

Kedudukan preference berkaitan dengan hasil eksekusi, hal ini nampak jelas bila dihubungkan dengan Pasal 1132 BW yang pada asasnya para kreditor berbagi atas hasil eksekusi harta benda milik debitor, dengan adanya pembebanan jaminan fidusia maka kreditor menjadi preference atas hasil penjualan benda tertentu milik debitur, dan ia berhak mengambil lebih dahulu uang hasil eksekusi benda jaminan fidusia.

2. Mempunyai kekuatan eksekutorial

Eksekusi terhadap objek jaminan fidusia dapat dilakukan berdasarkan grosse sertifikat jaminan fidusia sesuai dengan ketentuan Pasal 29 ayat (1) Undang-Undang jaminan fidusia atau dengan title eksekutorial sertifikat jaminan fidusia yang diberikan Pasal 15 ayat (2) Undang-Undang jaminan fidusia tersebut. Sertifikat jaminan fidusia mempunyai kekuatan eksekutorial sama seperti putusan pengadilan yang telah memperoleh kekuatan hukum tetap, maka 
pelaksanaan eksekusi objek jaminan fidusia berdasarkan grosse sertifikat jaminan fidusia atau dengan title eksekutorial sertifikat jaminan fidusia mengikuti pelaksanaan suatu putusan pengadilan. Atas dasar ini, penerima fidusia dengan sendirinya dapat mengeksekusi benda yang dijadikan sebagai objek jaminan fidusia jika debitur atau pemberi fidusia cedera janji, tanpa harus menunggu adanya surat perintah (putusan) dari pengadilan.

Berdasarkan pada buku panduan fidusia online, dalam sistem pendaftaran secara manual terdapat beberapa permasalahan yaitu sebagai berikut:

1. Ketentuan one day service tidak terpenuhi.

2. Belum ada keseragaman dalam pelayanan (SOP) sebagai panduan pelayanan permohonan jaminan fidusia.

3. Tingkat pemahaman sumber daya manusia di kanwil/kantor pendaftaran fidusia (KPF) masih tidak seragam.

4. Lonjakan permohonan pendaftaran jaminan fidusia yang signifikan melampaui kemampuan SDM dan sarana prasarana di setiap KPF.

5. Kepastian hukum tidak terpenuhi karena KPF belum memberikan kepastian penerbitan sertifikat jaminan fidusia karena tumpukan permohonan mencapai 1000 s/d 2000 permohonan setiap hari.

6. Belum ada pusat data yang terintegrasi antara kanwil dengan Ditjen Administrasi Hukum Umum selaku pembina teknis.

7. Terjadi penumpukan arsip pendaftaran fidusia di kanwil yang membutuhkan ruangan luas.
8. Adanya pungutan liar.

9. Biaya tinggi karena notaris ke KPF yang ada di ibukota provinsi.

Berkaitan dengan hal tersebut dan untuk memberikan pelayanan yang optimal dalam pendaftaran jaminan fidusia maka Direktorat Jenderal Administrasi Hukum Umum memberlakukan pendaftaran jaminan fidusia secara elektronik yang merubah sistem pendaftaran manual ke pelayanan pendaftaran yang berbasis elektronik (online). Fidusia online merupakan terobosan dari Direktorat Jenderal Administrasi Hukum Umum dalam memberikan pelayanan kepada masyarakat demi Indonesia yang lebih baik. Akibat yang timbul apabila jaminan fidusia tidak didaftarkan, pihak penerima tidak mempunyai posisi sebagai kreditor preference dan penerima fidusia akan mengalami kesulitan untuk mengeksekusi, apabila pihak debitur wanprestasi.

Sesuai dengan Pasal 29 ayat (1) Undang-Undang Jaminan Fidusia bahwa:

(1) Apabila debitur atau pemberi fidusia cidera janji, eksekusi terhadap benda yang menjadi obyek jaminan fidusia dapat dilakukan dengan cara:

a. pelaksanaan titel eksekutorial sebagaimana dimaksud dalam Pasal 15 ayat (2) oleh penerima fidusia;

b. penjualan benda yang menjadi obyek jaminan fidusia atas kekuasaan penerima fidusia sendiri melalui pelelangan umum serta mengambil pelunasan piutangnya dari hasil penjualan;

c. penjualan di bawah tangan yang dilakukan berdasarkan kesepakatan pemberi dan penerima fidusia jika dengan cara demikian dapat diperoleh harga tertinggi yang menguntungkan para pihak. 
Undang-Undang Jaminan Fidusia tidak mengatur tentang jaminan fidusia dengan sistem elektronik dan jaminan fidusia yang tidak didaftarkan, sehingga dapat memicu suatu bentuk perbuatan kesengajaan dari pihak-pihak untuk menunda atau bahkan tidak melakukan pendaftaran jaminan fidusia. Pendaftaran jaminan fidusia sangatlah penting karena berpengaruh terhadap kepastian hukum. Tujuan pendaftaran jaminan fidusia adalah untuk melindungi pihak kreditur sebagai penerima fidusia dari debitur yang melakukan wanprestasi. Dengan tidak terdapatnya aturan tersebut maka terjadi kekosongan norma, dalam hal menghadapi kekosongan hukum (rechts vacuum) atau kekosongan undang-undang (wet vacuum), hakim berpegang pada asas ius curia novit, dimana hakim dianggap tahu akan hukumnya. Hakim tidak boleh menolak suatu perkara dengan alasan tidak ada atau tidak jelas hukumnya. Ia dilarang menolak menjatuhkan putusan dengan dalih undang-undangnya tidak lengkap atau tidak jelas. Ia wajib memahami, mengikuti, dan menggali nilai-nilai hukum yang hidup dalam masyarakat. Oleh karena itu ia harus melakukan penemuan hukum (rechtvinding).

Penemuan hukum bukanlah merupakan ilmu baru, tetapi telah lama dikenal dan dipraktikkan selama ini oleh hakim, pembentuk undang-undang dan para sarjana hukum yang tugasnya memecahkan masalah -masalah hukum. Dalam literatur Belanda telah banyak orang yang menulis mengenai penemuan hukum (rechtsvinding). Penemuan hukum pada dasarnya merupakan kegiatan dalam praktik hukum (hakim, pembentuk undangundang dan sebagainya), akan tetapi penemuan hukum tidak dapat dipisahkan dari ilmu (teori) hukum.

\section{PENUTUP}

\section{A. Kesimpulan}

Dari pembahasan permasalahan di atas penulis dapat menyimpulkan bahwa :

1. Sistem pendaftaran jaminan fidusia secara elektronik. Pemohon tidak perlu lagi datang langsung di Kementrian Hukum dan HAM melainkan cukup mendaftarkan akta fidusia di website ditjen Administrasi Hukum Umum. Dengan mengikuti semua persyaratan yang ditentukan lalu pemohon melakukan pembayaran biaya pendaftaran jaminan fidusia melalui bank persepsi berdasarkan bukti pendaftaran. Pendaftaran jaminan fidusia dicatat secara elektronik setelah pemohon melakukan pembayaran biaya pendaftaran jaminan fidusia. Jaminan fidusia lahir pada tanggal yang sama dengan tanggal jaminan fidusia dicatat. Sertifikat jaminan fidusia ditandatangani secara elektronik oleh pejabat pada Kantor Pendaftaran Fidusia. Sertifikat jaminan fidusia dapat dicetak pada tanggal yang sama dengan tanggal jaminan fidusia dicatat.

2. Akibat hukum dari perjanjian jaminan fidusia yang tidak terdaftarkan dalam sistem elektronik adalah tidak melahirkan perjanjian kebendaan bagi jaminan fidusia tersebut, sehingga karakter kebendaan seperti droit de suite dan hak preferensinya tidak melekat pada kreditur pemberi jaminan fidusia. 


\section{B. Saran}

Terkait dengan pokok permasalahan dalam penelitian ini yang telah diuraikan pada bab-bab sebelumnya, maka dapa $t$ diberikan saran -saran sebagai berikut :

1. Saran yang pertama penulis tujukan untuk pemerintah, saat ini undangundang yang mengatur tentang fidusia yaitu Undang-Undang Nomor 42 Tahun 1999 tentang Jaminan Fidusia. Undang-undang tersebut dibuat sudah lama, sehingga diperlukan adanya penambahan-penambahan atau perubahan-perubahan terhadap aturan jaminan fidusia dengan memperhatikan kebutuhan masyarakat saat ini salah satu alasan nya adalah belum masuknya akibat jaminan fidusia yang tidak terdaftar dalam Undang-Undang tersebut.

2. Saran kedua penulis tujukan untuk pemberi fidusia, untuk mewujudkan kepastian hukum dan memenuhi asas publisitas dalam pendaftaran jaminan fidusia, hendaknya para pihak segera melakukan pendaftaran benda yang telah dibebani jaminan fidusia karena apabila tidak segera didaftarkan dalam waktu 30 hari maka akta fidusia tersebut akan hangus dan membutuhkan waktu lagi untuk membuatnya.

\section{DAFTAR PUSTAKA}

\section{A. Buku-Buku}

Mariaam Darus Badrulzaman. 1994. Aneka Hukum Bisnis. Bandung: Alumni

R Setiawan. 1978. Pokok-Pokok Hukum Perikatan. Bandung: Citra Aditya Bakti.
Supianto. 2015. Hukum Jaminan Fidusia. Yogyakarta: Garudhawaca

Tami Rusli. 2012. Hukum Perjanjian yang Berkembang Di Indonesia. Bandar Lampung: CV Anugrah Utama Raharja (AURA).

Thomas Suyatno. 2007. Dasar-Dasar Prekreditan. Jakarta: PT Gramedia Pustaka Utama.

\section{B. Undang-Undang}

Undang-Undang Nomor 10 Tahun 1998 tentang Perbankan.

Undang-Undang Nomor 42 Tahun 1999 tentang Jaminan Fidusia.

Peraturan Menteri Hukum dan Hak Asasi Manusia Republik Indonesia Nomor 10 tahun 2013 tentang Tata Cara Pendaftaran Jaminan Fidusia Secara Elektronik.

Peraturan Pemerintah Republik Indonesia Nomor 21 Tahun 2015 tentang Tata Cara Pendaftaran Jaminan Fidusia Dan Biaya Pembuatan Akta Jaminan Fidusia.

\section{Sumber Lain}

Aermadepa, 2012, "Pendaftaran Jaminan Fidusia, Masalah dan Dilema dalam Pelaksanaan", Jurnal Ilmiah Abdi Ilmu, Vol.5 No. 1 Tahun 2012.

Hukum Online, 2012, https://www.hukumonline.com/ berita/baca/lt5053293c df2da/pendaftaran-fidusia-masih-adakendala di akses di Bandar Lampung pada tanggal 1 Januari 2019 pukul 20.50 wib. 